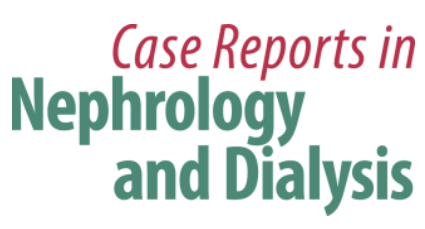

\title{
Automated Peritoneal Dialysis is Suitable for Polycystic Kidney Disease Patients with End-Stage Renal Disease
}

\author{
Xiao Li Hong Ren Jingyuan Xie Xiao-Min Huang Chun-Yan Zhang \\ Nan Chen \\ Department of Nephrology, Rui Jin Hospital, Shanghai Jiao Tong University School of \\ Medicine, Shanghai, China
}

\section{Key Words}

Polycystic kidney disease - End-stage renal disease - Renal replacement therapy - Automated peritoneal dialysis

\begin{abstract}
A female patient with polycystic kidney disease (PKD) was treated with automated peritoneal dialysis when she reached end-stage renal disease. The patient has been doing very well on automated peritoneal dialysis (APD) for almost 6 years without peritonitis or abdominal hernias. Intra-abdominal pressures are lower in the supine position than in an erect or sitting position. Larger volumes of dialysate are better tolerated while the patient is supine, as during nocturnal APD. Therefore, APD is an option of the renal replacement therapy for patients with PKD.

(C) 2015 S. Karger AG, Basel
\end{abstract}

\section{Introduction}

Autosomal polycystic kidney disease (PKD) is the most common monogenic renal disease [1]. There are about 400-600 million PKD patients all over the world. The United States renal data system (USRDS) reports that 20,000 patients with PKD progress into end-stage renal disease (ESRD) each year in the United States. By the end of 2011, a total of 395 patients with PKD were undergoing dialysis in Shanghai; this accounted for $3.15 \%$ of all dialy- 


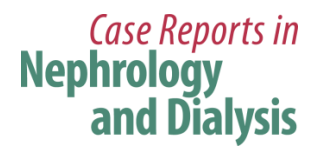

\begin{tabular}{l|l}
\hline \multicolumn{2}{l|}{ Case Rep Nephrol Dial 2015;5:140-144 } \\
\hline DOI: $10.1159 / 000431083$ & $\begin{array}{l}\text { C } 2015 \text { S. Karger AG, Basel } \\
\text { www.karger.com/cnd }\end{array}$ \\
\hline
\end{tabular}

Li et al.: Automated Peritoneal Dialysis is Suitable for Polycystic Kidney Disease Patients with End-Stage Renal Disease

sis patients, only less than glomerulonephritis, diabetic nephropathy and hypertensive renal sclerosis [2].

What's the better option in renal replacement therapy for PKD patients with ESRD, peritoneal dialysis (PD) or hemodialysis (HD)? The answer is quite controversial. We introduced a patient with $\mathrm{PKD}$, treated by automated peritoneal dialysis (APD).

\section{Case Presentation}

A female, born in 1965, was admitted to our Nephrology Department in December 2008.

\section{History of Present Illness}

PKD was found 20 years ago via a physical examination (with no specific treatment). Her annual physical examination showed a normal serum creatinine level. In January 2007, her serum creatinine level was elevated to $247 \mu \mathrm{mol} / \mathrm{l}$. The patient was treated with antihypertensive medications. She received a renal cyst puncture and ethanol injection at the other hospital on August 29, 2008. She suffered from a cyst infection with high fever; she was then given positive antiinfective therapy. Her body temperature returned to normal while her renal function deteriorated further. The serum creatinine level was $648 \mu \mathrm{mol} / \mathrm{l}$, albumin was $33 \mathrm{~g} / \mathrm{l}$, and hemoglobin was $87 \mathrm{~g} / \mathrm{l}$ before the admission. A renal replacement therapy was considered.

\section{Past Medical History}

She had hypertension for 10 years. She suffered from a cerebral hemorrhage in 2001, which caused weakness in her right extremities.

\section{Personal History}

Our patient is married. She has a healthy daughter and denies any tobacco and alcohol addiction. Her mother and an uncle suffered from PKD.

\section{Physical Examination}

Her body temperature was $36^{\circ} \mathrm{C}$, pulse $80 / \mathrm{min}$, respiratory rate $20 / \mathrm{min}$, blood pressure $110 / 60 \mathrm{~mm} \mathrm{Hg}$, and body surface $1.67 \mathrm{~m}^{2}$. The patient appeared to be oriented and cooperative. She looked pale. She had a normal skin appearance, texture, and temperature. No palpable nodes were in the cervical, supra-clavicular, axillary or inguinal areas. Her oral pharynx was normal without erythema or exudate. The neck was easily movable without any resistance, no abnormal adenopathy in the cervical or supraclavicular areas was observed. The trachea was midline and the thyroid gland was normal without any visible masses. Her lungs were clear to auscultation and percussion bilaterally. The heart rate was $80 \mathrm{bmp}$ with a regular rhythm and no murmur. The abdomen was distended; bowel sounds were normal. Her enlarged kidneys were palpable and no edema was found in both lower extremities; her muscle strength of the right limbs was grade IV.

\section{Laboratory Findings}

Full blood count was as follows: white blood cells $5.4 \times 10^{9} / \mathrm{l}$, red blood cells $3.20 \times$ $10^{12} / \mathrm{l}$, hemoglobin $95 \downarrow \mathrm{g} / \mathrm{l}$, platelets $216 \times 10^{9} / \mathrm{l}$. Fast blood glucose $4.90 \mathrm{mmol} / \mathrm{l}$, alanine aminotransferase $9 \mathrm{IU} / \mathrm{l}$, glutamic oxalocetie transaminase $12 \mathrm{IU} / \mathrm{l}$, prealbumin $208 \mathrm{mg} / \mathrm{l}$, alkaline phosphatase $47 \mathrm{IU} / \mathrm{l}, \mathrm{r}$-GT $15 \mathrm{IU} / \mathrm{l}$, total bilirubin $13.1 \mu \mathrm{mol} / \mathrm{l}$, direct bilirubin 1.6 $\mu \mathrm{mol} / \mathrm{l}$, total protein $73 \mathrm{~g} / \mathrm{l}$, albumin $36 \mathrm{~g} / \mathrm{l}$, blood urea nitrogen $24.0 \uparrow \mathrm{mmol} / \mathrm{l}$, serum creat- 


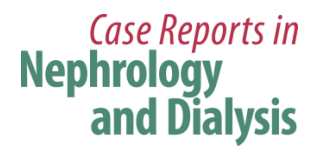

\begin{tabular}{l|l}
\hline \multicolumn{2}{l|}{ Case Rep Nephrol Dial 2015;5:140-144 } \\
\hline DOI: $10.1159 / 000431083$ & $\begin{array}{l}\text { C } 2015 \text { S. Karger AG, Basel } \\
\text { www.karger.com/cnd }\end{array}$ \\
\hline
\end{tabular}

Li et al.: Automated Peritoneal Dialysis is Suitable for Polycystic Kidney Disease Patients with End-Stage Renal Disease

inine $731.0 \uparrow \mu \mathrm{mol} / \mathrm{l}$, uric acid $390 \mu \mathrm{mol} / \mathrm{l}$, triglyceride $1.20 \mathrm{mmol} / \mathrm{l}$, total cholesterol 3.94 mmol/l, sodium $138.5 \mathrm{mmol} / \mathrm{l}$, potassium $4.45 \mathrm{mmol} / \mathrm{l}$, calcium $2.32 \mathrm{mmol} / \mathrm{l}$, phosphorus $1.68 \mathrm{mmol} / \mathrm{l}$, ferritin $57.8 \mathrm{ng} / \mathrm{ml}$, transferrin $189 \mathrm{mg} / \mathrm{dl}$, serum ferrium $7.6 \mathrm{umol} / \mathrm{l}$, iron saturation $17.0 \%$, total iron binding capacity $44.8 \mu \mathrm{mol} / \mathrm{l}$, parathyroid hormone $131.2 \mathrm{pg} / \mathrm{ml}$. A B-ultrasound scan showed intrahepatic cystic lesions and liver cysts should be considered; the kidneys were significantly enlarged (occupied in the upper abdomen, down to the pelvis), consistent with polycystic kidney disease. Electrocardiogram was normal. Echocardiography: ejection fraction was $62 \%$. A head enhanced CT scan performed in another hospital showed a possible cerebral aneurysm.

\section{Treatment}

Losartan (50 mg 1 tablet, once a day, p.o.), levamlodipine (2.5 mg 1 tablet, once a day, p.o.), clonidine ( $75 \mu \mathrm{g} 1$ tablet, three times a day, p.o.), calcitriol ( $0.25 \mu \mathrm{g} 1$ tablet, once a day , p.o.), calcitrate $\mathrm{D}$ ( $0.6 \mathrm{~g} 1$ tablet, once a day , p.o.), bicarbonate ( $500 \mathrm{mg} 2$ tablets, three times a day, p.o.), ferrous succinate (100 $\mathrm{mg} 2$ tablets, three times a day, p.o.). A laparoscopic peritoneal dialysis catheter insertion was performed on December 9, 2008, and automated peritoneal dialysis was started after 2 weeks. The treatment protocol consisted of $1.5 \%$ peritoneal dialysate ( 8 liters, 2 liters $\times 4$ cycles in a total of $10 \mathrm{~h}$; nocturnal). The patient has been doing very well on APD for almost 6 years (table 1). She has never suffered from peritonitis or abdominal hernias.

\section{Discussion}

It is commonly believed that PKD patients on PD are overexposed to technique failure and peritonitis compared to other patients. Extrarenal manifestations of PKD, such as diverticulosis, development of hernias or vascular aneurysms, may theoretically promote the occurrence of complications typically related to PD. Nevertheless, enlarged kidneys occupying most of the abdominal cavity space might reduce the available peritoneal surface area, restricting the dialysis volume. Thus, most patients with PKD progressing to ESRD are usually referred to hemodialysis. The report of Shanghai Renal Registry [2] shows that patients with ESRD caused by PKD are less frequently treated with PD than patients with noncystic renal diseases (7.5 vs. $24.1 \%$ ). In contrast, USRDS reports that more than $20 \%$ of PKD patients choose PD as their initial form of renal replacement therapy, while only $15 \%$ are shown in non-PKD renal failure patients [3].

Is peritoneal dialysis appropriate for PKD patients with ESRD? Hadimeri et al. [4] compared survival and complications between 26 patients with autosomal dominant polycystic kidney disease (ADPKD) under continuous ambulatory peritoneal dialysis (CAPD) and 26 controls without ADPKD or diabetic nephropathy. They found that it is similar in survival rate in ADPKD patients and controls. Hernia was present in 4 ADPKD patients and 2 controls, and 1 patient was required to transfer to HD temporarily in each group. The incidence of peritonitis was 1 in 20 months in ADPKD patients versus 1 in 27 months in controls (not significantly different). Peritonitis caused by colonic bacteria was in similar numbers. Residual renal function was similar in ADPKD patients and controls. No difference was detected in any of the variables measured by peritoneal dialysis capacity. A retrospective cohort study [5] based on the data of the French Language Peritoneal Dialysis Registry also suggested that PD is a suitable method for at least a subgroup of PKD patients reaching end-stage renal disease in a country where renal transplantation is available. 


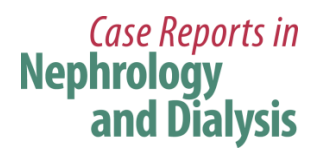

\begin{tabular}{l|l}
\hline \multicolumn{2}{l}{ Case Rep Nephrol Dial 2015;5:140-144 } \\
\hline DOI: 10.1159/000431083 & $\begin{array}{l}\text { ○ 2015 S. Karger AG, Basel } \\
\text { www.karger.com/cnd }\end{array}$ \\
\hline
\end{tabular}

Li et al.: Automated Peritoneal Dialysis is Suitable for Polycystic Kidney Disease Patients with End-Stage Renal Disease

Xie et al. [6] retrospectively analyzed 29 patients with PKD who needed dialysis therapy for over 3 months in our department. They were treated with CAPD $(n=10)$ and HD $(n=$ 19), and 10 CAPD patients with non-PKD served as controls. No significant difference existed in the survival rates of 1-, 3- and 5-years among 3 groups. Kt/V per week, creatinine clearance, residual renal function, peritoneal transport characteristics, $24 \mathrm{~h}$ urine and ultrafiltration were similar between PKD and non-PKD CAPD patients. No patient changed to HD due to inadequate PD dialysis. We concluded that the prognosis and complication incidence in PKD and non-PKD patients treated with CAPD are similar, and the prognosis of PKD patients treated with CAPD or HD is also similar.

Abdominal hernias and peritoneal leaks are very frequent in the PD population. Advanced age, PKD and a high body mass index are independent risk factors for their development [7]. However, there are some advantages of APD in patients with PKD. The patient with PKD introduced above has been doing very well on APD for almost 6 years. She has never suffered from peritonitis or abdominal hernias. Because intra-abdominal pressures are lower in the supine position than in the erect and sitting position, larger volumes of dialysate are better tolerated while the patient is supine (as during nocturnal APD) [8]. The above patient has excellent residual renal function (renal creatinine clearance was between 52.51 and 62.38 liters/week) and well controlled in blood pressure. Increased and individualized dwell volumes and prescriptions for suitable total volumes per session in APD permit longer dwell times and allow for better results in patients with a peritoneal permeability lower than the mean. In order to avoid peritoneal leaks and hernia, APD treatment with low daytime exchange volumes must be considered in those patients with PKD [7].

In conclusion, the technical survival, quality of dialysis, duration of therapy and rates of complications in PD are comparable in patients with cystic or noncystic kidney disease, and therefore all patients with PKD who do not have abdominal complaints or a history of recurrent hernias should be informed that PD is an adequate form of renal replacement therapy. Moreover, APD is a suitable method of renal replacement therapy for PKD patients with ESRD due to its flexibility and effectiveness.

\section{Disclosure Statement}

On behalf of Dr. Chen Nan and the other authors, we declare that no financial or other conflict of interest exists in relation to the content of the paper.

\section{References}

1 Torres VE, Harris PC, Pirson Y: Autosomal dominant polycystic kidney disease. Lancet 2007;369:12871301.

2 Report of Shanghai Renal Registry, 2013 .http://sh.cnrds.org.

3 Prischl FC, Dieplinger G, Wallner M, Seiringer E, Hofinger I, Kramar R: Peritoneal dialysis in patients with polycystic kidney disease (in German). Wien Klin Wochenschr 2005;117(suppl 6):24-28.

4 Hadimeri H, Johansson AC, Haraldsson B, Nyberg G: CAPD in patients with autosomal dominant polycystic kidney disease. Perit Dial Int 1998;18:429-432.

5 Lobbedez T, Touam M, Evans D, Ryckelynck JP, Knebelman B, Verger C: Peritoneal dialysis in polycystic kidney disease patients. Report from the French peritoneal dialysis registry (RDPLF). Nephrol Dial Transplant 2011;26:2332-2339.

6 Xie JY, Chen N, Ren H, Chen XN, Zhang W, Xu J, Zhu P: Comparative study of continuous ambulatory peritoneal dialysis and hemodialysis on polycystic kidney disease patients. Chin J Nephrol 2009;25:101105. 
Case Reports in

Nephrology

and Dialysis

\begin{tabular}{l|l}
\hline \multicolumn{2}{l}{ Case Rep Nephrol Dial 2015;5:140-144 } \\
\hline DOI: 10.1159/000431083 & $\begin{array}{l}\text { ○ 2015 S. Karger AG, Basel } \\
\text { www.karger.com/cnd }\end{array}$ \\
\hline
\end{tabular}

Li et al.: Automated Peritoneal Dialysis is Suitable for Polycystic Kidney Disease Patients with End-Stage Renal Disease

7 Del Peso G, Bajo MA, Costero O, Hevia C, Gil F, Díaz C, Aguilera A, Selgas R: Risk factors for abdominal wall complications in peritoneal dialysis patients. Perit Dial Int 2003;23:249-254.

8 Amici G, Virga G, Ronco C: Automated peritoneal dialysis: when and how to do it. Perit Dial Int 1999;19(suppl 2):S115-S120.

Table 1. Dialysis adequacy parameters after starting APD

\begin{tabular}{llll}
\hline Months after APD & Kt/V, /week & Ccr, l/week & 24 h urine, ml \\
\hline 1 & 2.98 & 75.20 & 1,400 \\
6 & 3.12 & 84.02 & 2,000 \\
12 & 3.3 & 88.16 & 1,400 \\
54 & 4.25 & 90.06 & 1,500 \\
70 & 2.38 & 48.89 & 1,100 \\
\hline
\end{tabular}

Ccr $=$ Creatinine clearance. 